\title{
Exogenous leptin does not affect exocrine pancreatic secretion in conscious sheep*
}

\author{
W. Korczyński ${ }^{1}$, D. Kirat ${ }^{2}$ and S. Kato ${ }^{2}$ \\ ${ }^{1}$ The Kielanowski Institute of Animal Physiology and Nutrition, Polish Academy of Sciences \\ 05-110 Jabłonna, Poland \\ ${ }^{2}$ Department of Physiology, School of Veterinary Medicine, Rakuno Gakuen University \\ Ebetsu, 069-8501 Hokkaido, Japan
}

\begin{abstract}
The experiment was performed on 10 Black Suffolk sheep of $59 \pm 8 \mathrm{~kg}$ BW. The animals were equipped with two catheters in common bile duct and one in duodenum and set of three bipolar electrodes sutured on the duodenum. In accordance to duodenal electromyography activity, effect of exogenous leptin on pancreatic juice secretion was studied. Administration of leptin $\left(2-10 \mu \mathrm{g} \mathrm{kg}^{-1}\right.$ BW intravenously) did not affect the volume, protein, amylase and bicarbonates output in pancreatic juice. In conclusion, the results suggest, that in the doses used, leptin have no effect on pancreatic secretion.
\end{abstract}

KEY WORDS: leptin, exocrine pancreatic secretion, electromyography, sheep

\section{INTRODUCTION}

Leptin is a 167 amino acids long, cytokine family hormone, secreted predominantly by white adipose tissue. It acts as a long term satiety signal by inhibition of neuropeptide Y (NPY) release from hypothalamus resulted in reduction of food intake and body mass (Schwartz et al., 2000). Bado et al. (1998) found, as the first link between leptin and the GI tract, that leptin is produced in the fundic part of rat stomach mucosa. After a meal it is rapidly mobilized and released into local blood circulation. In the stomach, leptin interacts with autonomic nervous system to modify the sensor information that reaches the brain via vagal afferent fibres, and can have modulatory effect on efferent pathways of vago-vagal reflex. There are two types of leptin-sensitive vagal afferent fibres

\footnotetext{
* Supported by Japanese Society Promotion of Science

${ }^{1}$ Corresponding author: e-mail: w.korczynski@ifzz.pan.pl
} 
in the stomach: one is dependent on previous cholecystokinin (CCK) activation (Wang et. al., 1997). Leptin modifies insulin release (Fehmann et al., 1997; Tanizawa et al., 1997). It was proposed that an adipo-insular axis exists in which leptin plays a negative feedback role transferring signals from adipose tissue to the endocrine pancreas.

Leptin administration decreased (Bilski et al., 2000; Matyjek et al., 2003) or increased (Guilmeau et al., 2002) pancreato-biliary secretion (PBJ) in anaesthetized rats. Harris et al. (1999) reported an CCK dependent increase of amylase release from cultured rat pancreas cancer line cells in vitro. However, there is lack of data about the influence of leptin on exocrine pancreatic secretion in ruminants in chronic experiments.

\section{MATERIAL AND METHODS}

Ten mature male Black Suffolk sheep ( $59 \pm 8 \mathrm{~kg} \mathrm{BW})$, were used. The animals were kept in metabolic cages at daylight conditions in a temperature-controlled room. The sheep were fed hay $(200 \mathrm{~g})$ and lucerne pellets $(2 \% \mathrm{BW})$, once a day at 6 p.m. and free access to water. A duodenal cannulae and two catheters in the common bile duct, for separate collection of bile and pancreatic juice, were implanted. Secretions were returned to duodenum by peristaltic pump. Electrodes for electromyography (EMG) (Gacsalyi et al., 2000) was sutured on duodenum. Cables were connected to a bioelectric amplifiers (Nihon-Kohden) recording system (BioAmp, MacLab system). Animals were equipped with indwelling catheters into external jugular vein. Pancreatic juice was collected in 10 min intervals from the beginning of phase III of migrating myolectrical complex (MMC). After bolus saline i.v. injection, control sampling, and EMG recording were performed for one MMC (1.5-3 h). Next mouse recombinant leptin (Alpha Diagnostic International, USA) was administered i.v in bolus injection in the late phase I of MMC at dose: $0.5 \mu \mathrm{g} \mathrm{kg}^{-1}, 2 \mu \mathrm{g} \mathrm{kg}^{-1}$ and $10 \mu \mathrm{g} \mathrm{kg}^{-1} \mathrm{BW}$. After that, sampling and recording were continued for another MMC cycle. In each sample, volume, protein (Lowry method), bicarbonates concentration (titration $0.01 \mathrm{~N} \mathrm{NaOH}$ ) and amylase activity (Bernfeld method) were estimated and calculated as outputs. Results were evaluated by Friedman ANOVA and MannWhitney tests (Statistica 5.1 for Windows - Statsoft, Tulsa, USA) and expressed as means $\pm \mathrm{SE}$.

\section{RESULTS}

Leptin administration had no statistically significant effect on all parameters of the exocrine pancreatic secretion recorded in accordance with EMG changes (Table 1). There was a tendency towards higher juice output in $10 \mu \mathrm{g} \mathrm{kg}^{-1} \mathrm{BW}$ leptin treatment $(\mathrm{P}=0.07)$. Typically in sheep, the lowest volume of pancreatic juice was recorded during phase III of MMC. 
Table 1. Effect of exogenous leptin on pancreatic juice secretion in sheep (mean $\pm \mathrm{SE}$ )

\begin{tabular}{lcccc}
\hline \multirow{2}{*}{ Parameter } & \multicolumn{4}{c}{ Leptin dose, $\mu \mathrm{g} \mathrm{kg}^{-1} \mathrm{BW}$ i.v } \\
\cline { 2 - 5 } & control & 0.5 & 2 & 10 \\
\hline Juice output, $\mathrm{ml} 10 \mathrm{~min}^{-1}$ & $3.41 \pm 0.16$ & $3.49 \pm 0.19$ & $3.80 \pm 0.11$ & $3.90 \pm 0.31$ \\
Protein output, mg $10 \mathrm{~min}^{-1}$ & $142.7 \pm 11.8$ & $150.5 \pm 10.5$ & $146.5 \pm 12.7$ & $161.6 \pm 7.1$ \\
Amylase activity, $\mathrm{kU} 10 \mathrm{~min}^{-1}$ & $16.1 \pm 1.2$ & $15.4 \pm 1.2$ & $18.5 \pm 1.0$ & $16.9 \pm 0.6$ \\
Bicarbonates output, $\mathrm{mEq} 10 \mathrm{~min}^{-1}$ & $0.74 \pm 0.14$ & $0.81 \pm 0.22$ & $0.79 \pm 0.16$ & $0.85 \pm 0.25$ \\
\hline
\end{tabular}

\section{DISCUSSION}

To our knowledge there is the first communication concerning leptin action on the exocrine pancreatic secretion in sheep. We used leptin in physiological doses. The highest leptin dose $10 \mu \mathrm{g} \mathrm{kg}^{-1} \mathrm{BW}$ exceeded 50 times normal sheep serum leptin level (i.e. $5 \mathrm{ng} \mathrm{ml}^{-1}$ ) (Ehrhardt et al., 2000). Leptin was administered always in the late phase I of MMC, because it is well known that action of the GI tract hormones depends on the motility (Zabielski et al., 1998). In the present study leptin has not affected the pancreatic juice secretion, however a tendency to increase the volume was observed. In general, it confirms findings of Matyjek et al. (2003), that leptin given at the same dose range had no effect on volume of PBJ in anaesthetized rats. However, in the same study administration of leptin led to decrease of protein output in PBJ but had no effect on amylase release from pancreatic acini in vitro. In contrast, in study of Guilmeau et al. (2002) exogenous leptin administration (30-100 $\mathrm{nmol}^{-1} \mathrm{~kg} \mathrm{BW}$ ) produced dose related increase of volume, protein and bicarbonates output in PBJ. In the same study it was shown that high doses of leptin can release CCK, and it is possible that leptin effect on PBJ was indirect. However, the smallest leptin dose $3 \mathrm{nmol} \mathrm{kg}{ }^{-1}$ BW used in the experiment, which corresponds to $20 \mu \mathrm{g} \mathrm{kg}^{-1}$, was not effective. Further studies are needed to elucidate effect of leptin on pancreatic secretion in ruminants.

\section{CONCLUSIONS}

Exogenous leptin infused intravenously had no effect on the exocrine pancreatic secretion in conscious sheep in chronic experiment.

\section{REFERENCES}

Bado A., Levasseur S., Attoub S., Kermorgant S., Laigneau J.P., Bortoluzzi M.N., Moizo L., Lehy T., Guerre-Millo M., Le Marchand-Brustel Y., Lewin M.J.M., 1998. The stomach is a source of leptin. Nature 394, 790-793

Bilski J., Szlachcic A., Jaworek J., Bonior J., Dembinski A., 2000. Effect of leptin on stimulated pancreatic secretion in vivo and in vitro. Neurogastroenterol. Motil. 12, 377 (Abstr.) 
Ehrhardt R.A., Slepetis R.M., Siegal-Willot J., Van Amburgh M.E., Bell A.W., Boisclair Y.R., 2000. Development of specific radioimmunoassay to measure physiological changes of circulating leptin in cattle and sheep. J. Endocrinol. 166, 519-528

Fehmann H.Ch., Peiser Ch., Bode H.P., Stamm M., Staas P., Hedetoft Ch., Lang R.E., Göke B., 1997. Leptin: a potent inhibitor of insulin secretion. Peptides 18, 1267-1273

Gacsalyi U., Zabielski R., Pierzynowski S.G., 2000.Telemetry facilitates long-term recording of gastrointestinal myoelectrical activity in pigs. Exp. Physiol. 85, 239-241

Guilmeau S., Nagain-Domaine C., Buyse M., Tsocas A., Roze C., Bado A., 2002. Modulation of exocrine pancreatic secretion by leptin through CCK1-receptors and afferent vagal fibres in the rat. Eur. J. Pharmacol. 447, 99-107

Harris D.M., Flanningan K.L., Go V.L., Wu S.V., 1999. Regulation of cholecystokinin-mediated amylase secretion by leptin in rat pancreatic acinar tumor line AR42J. Pancreas 19, 224-230

Matyjek R., Herzig K.-H., Kato S., Zabielski R., 2003. Exogenous leptin inhibits the secretion of pancreatic juice via duodenal CCK1-vagal-dependent mechanism in anaesthetized rats. Regul. Peptides 114, 15-20

Schwartz M.W., Woods S.C., Porte D. Jr., Seeley R.J., Baskin D.G., 2000. Central nervous system control of food intake. Nature 404, 661-671

Tanizawa Y., Okuya S., Ishihara H., Asano T., Yada T., Oka Y., 1997. Direct stimulation of basal insulin secretion by physiological concentrations of leptin in pancreatic $\beta$ cells. Endocrinology 138, 4513-4516

Wang Y.H., Taché Y., Sheibel A.B., Liang V., Go W., Wei J.Y., 1997. Two types of leptin-responsive gastric vagal afferent terminals: and in vitro single-unit study in rats. Amer. J. Physiol. 273, R833-R837

Zabielski R., Dardillat C., Le Huerou-Luron I., Bernard C., Chayvialle J.A., Guilloteau P., 1998. Periodic fluctuations of gut regulatory peptides in phase with the duodenal migrating myoelectric complex in preruminating calves: effect of different sources of dietary protein. Brit. J. Nutr. 79, 287-296 